\title{
Catechins Green Tea GMB4 Clone Increases mRNA of ABCA1 through LXR Signaling in Cultured Macrophage Exposed OX-LDL
}

\author{
Erna Susanti ${ }^{*}$, Retty Ratnawati ${ }^{2}$, Aulanni'am Aulanni'am², Achmad Rudijanto ${ }^{2}$ \\ ${ }^{1}$ Pharmacy and Food Analysis Academy "Putra Indonesia Malang”, Malang, Indonesia \\ ${ }^{2}$ Doctoral Program of Biomedical Science, Medical Faculty, Brawijaya University, Malang, Indonesia \\ Email: *abiyatur@gmail.com
}

How to cite this paper: Susanti, E., Ratnawati, R., Aulanni'am, A. and Rudijanto, A. (2019) Catechins Green Tea GMB4 Clone Increases mRNA of ABCA1 through LXR Signaling in Cultured Macrophage Exposed OX-LDL. Food and Nutrition Sciences, 10, 1179-1190.

https://doi.org/10.4236/fns.2019.109085

Received: April 3, 2018

Accepted: September 26, 2019

Published: September 29, 2019

Copyright (อ 2019 by author(s) and Scientific Research Publishing Inc. This work is licensed under the Creative Commons Attribution International License (CC BY 4.0).

http://creativecommons.org/licenses/by/4.0/

\begin{abstract}
Inhibition of atherogenesis through inhibition of lipid metabolism has not been explored while other inhibitions through inflammation, endothelial dysfunction and free radicals have done. Inhibition of atherogenesis via inhibition of lipid metabolism can be done through the mechanism of Reverse Cholesterol Transport (RCT). Signaling pathways that play a role in this mechanism is LXR signaling. LXR activation by an LXR agonist led increasing cholesterol efflux. Catechins based on bioinformatics study showed as a potent candidate LXR agonists that can be used as an inhibitor of atherogenesis. This study aims to prove that the administration Catechins green tea Clone GMB4 can prevent atherosclerosis through increasing mechanism cholesterol efflux from macrophage by taking effect of ABCA1, ABCG1, SRB1 gene expression in cultured macrophages were exposed ox-LDL. Long-term goals of the outcome of the research are the use of Catechins Green Tea Clones GMB4 as an inhibitor of atherogenesis so that it can be used as a complementary therapy for the treatment of atherosclerosis and cardiovascular diseases. The research is divided into 5 groups, namely the culture of macrophages without exposed ox-LDL, culture exposed ox-LDL and groups of Catechins dose I, II, III. In vitro study showed that administration of Catechins increases mRNA of ABCA1, whereas mRNA ABCG1 and SRB1 decreased at all three doses given. The result of protein profilling was identified a protein with a molecular weight of $70 \mathrm{kDa}$ by SDS-PGE with silver staining.
\end{abstract}

\section{Keywords}

Atherogenesis, Catechins, ABCA1, ABCG1 Dan SRB1, Cultured Macrophage 


\section{Introduction}

Cardio vascular disease (CVD) is first cause of death in the world. Atherosclerosis is the main contributor cause of death because the trigger of myocardial infarction and ischemic stroke. Based on WHO data, CVD mortality rate is estimated at $36.3 \%$ ( 1 of 2.3 of the total number of deaths) in the United States in 2004. While the costs for CVD in 2007 was reported at $\$ 431.8$ billion [1]. The process of atherogenesis can be initiated by high LDL that cause endothelial injury that trigger endothelial dysfunction. The next process, NADPH oxidase oxidized LDL endothelial cells. LDL modification that caused enzymatic and oxidative reaction triggers the release of inflammatory lipid which induces endothelial cells express leukocyte adhesion molecules. Modified LDLs were scavenged by scavenger receptors of macrophages that develop into foam cells [2]. One pathway inhibits atherosclerosis through a mechanism of reverse cholesterol transport (RCT). Reverse cholesterol transport is the process efflux cholesterol macrophages to HDL or lipid-free apolipoprotein like Apo-A1 or Apo E [3]. Further, HDL or Apo A1 is uptaked by the liver where free cholesterol in the liver to be excreted into the bile ducts in the form of cholesterol that is not changed or after converted into bile acids. The next process is the transport of intestinal cholesterol to be excreted through the feces. One of the signaling pathways that contribute to the inhibition of atherosclerosis through mechanisms RCT is LXR. Liver X receptors act as sensors of cholesterol that works to lower cholesterol levels through increasing the expression of a target gene associated with RCT that are the protein transporter ATP-binding cassette subfamily A member 1 (ABCA1), ATP-binding cassette subfamily G member 1 (ABCG1), Apo A1 and hepatic scavenger receptor class B type I (SRB1) [4].

LXR signaling is activated by an agonist effect on effluks cholesterol in macrophages which can be seen by inspection parameter ABCA1, ABCG1, Apo A1 and SRB-1. LXR clicking the upregulation of expression of ABCA1 transporter and ABCG1 whose role is to transport cholesterol from the plasma membrane to the extracellular acceptor. ABCA1 is a major protein for cellular cholesterol to Apo effluks acceptor such as ApoA1 and the first step in RCT. ABCA1 transporter is also a fully working as a single molecule to transfer cholesterol and phospholipids in the plasma membrane into pre high density lipoprotein (HDL) and lipid-free ApoA1. While working as a homodimer ABCG1, the transfer of cholesterol to HDL is not a lipid-free ApoA1 (Julve et al., 2011). Intervention therapy for improving the expression of ABCA1 and ABCG1 is an effective strategy to increase RCT macrophages and potentially reducing atherosclerosis. While Scavenger receptor $\mathrm{B} 1$ is a key receptor responsible for the selective uptake of cholesterol ester (CE) from HDL to the liver, the hepatic SRB1 positive regulator known as RCT. Without the SRB1, macrophages RCT will not run. The role of SRB-1 against the uptake of cholesterol in the liver and affect RCT research supported Zhang et al. (2005) [5]. Other studies El Bouhassani et al. (2011), Zhao et al. (2011) shows the results of the same study that mice with knockout 
SRB1 will reduce RCT. Based on the above research proves that the SRB-1 plays a role in RCT through the uptake of cholesterol by the liver. Based on the above background research is needed on the role of Catechins in inhibiting atherogenesis through increased effluks cholesterol through the RCT with the ABCA1 gene expression parameter, ABCG1 and SRB1 [6] [7].

Macrophages are the first inflammatory cells that cause atherosclerotic lesions that are major components of atherosclerotic plaque. In the pathogenesis of atherosclerosis, monocyte infiltration of blood to the intima and subintima, a process which are activated by the accumulation of lipoproteins containing apolipoprotein B (apoB-LPs) subendothelial. The presence of chemokines would cause the monocytes bind to the endothelium by effecting of P-selectin, E-selectin, Lymphocyte Function-Associate Antigen-1 (LFA-1), verry late antigen-4 (VLA-4), Vascular Cell Adhesion Molecule-1 (VCAM-1) and Intracellular Cell Adhesion Molecule-1 (ICAM-1), which in turn will monocytes enter the subendothelial so that is known diapedesis. The next phase occurs macrophage differentiation influenced by Macrophage Colony Stimulating Factor (MCSF). M1 differentiated from high Ly6C monocytes that cause inflammation, which is activated by Lipopolisacharide (LPS) in the presence of interferon- $\gamma$ (IFN $\gamma$ ), which triggers the production of interleukin-2 (IL-2), Interleukin-23 (IL-23), interleukin-6 (IL-6), Interleukin-1 (IL-1) and Tumor Necrosis Factor- $\alpha(\mathrm{TNF} \alpha)$ at high levels. While M2 differentiate from low Ly6C monocytes that play a role of inflammation. This differentiation is effected by IL-4, IL-13, IL-1 and vitamin D3 so that lead to produce IL-10, expression of scavenger receptors, mannose receptors and arginase in large quantities. In the development of atherosclerosis there is an imbalance between M1 and M2 [8]. Atherogenesis process can be inhibited by a mechanism RCT. The RCT mechanism activated by LXR signaling. LXR/RXR heterodimer binds to LXR response element (LXRE) containing sequences hexamerik (AGGTCA). LXR/RXR can be activated by LXR agonists and 9-C is Retinoic Acid (9cRA), RXR specific ligands. These receptors can also be activated synergistically with the ligand for the two receptors. Activators of endogenous LXR is oxysterol, oxidized cholesterol derivatives, namely 22-(R)-, 20-(S)-, 24-(S)-hydroxycholesterol dan 24-(S), 25-Epoxycholesterol which induces transcriptional activity of LXR at physiological concentrations, Coactivator for LXR transactivation are Grip 1, Ap 160 Coactivator, TRRAP, PGC- $1 \alpha$. PGC-1 $\alpha$ not only as a key regulator of hepatic gluconeogenesis but as Coactivator LXR $\alpha$. In the absence of ligand, nuclear receptor represses gene transcription by recruiting corepresor proteins such as nuclear receptor corepressor (NCoR) and silencing mediator of retinoic acid and thyroid hormone receptor (SMRT). Transrepression by LXR depends on the interaction NCoR and SMRT [9]. Activation of LXR signaling increases choleterol efflux through increasing protein transporter ABCA1, ABCG1 and SRB1. ABCA1 gene is expressed in high amounts in liver, testis, small intestine, adrenal glands, heart, brain and macrophages. ABCA1 gene expression is regulated by intracellular cholesterol levels. mRNA of ABCG1 is expressed at moderate to high levels on macrophages, spleen, lung, thymus, 
placenta, brain and at low levels in other tissues, liver. One of the natural substances that can potentially increase cholesterol efflux from macrophage is Green Tea GMB4 clone. Green tea is developed by the Centre for Development of Tea and Quinine Gambung with the high content of Catechins. Based on the results of analysis total Catechins from Green Tea clones GMB4 are 14\% - 16\% [10]. "Catechins" is a group of flavonoid consisting of Epicatechin (EC), Epigallocatechin (EGC), Epicatechin Gallate (ECG), Epigallocatechin gallate (EGCG), catechin, gallocatechin, catechin gallate, gallocatechin gallate [11].

\section{Method}

Isolation of Catechins Green Tea GMB4 clone conducted at the Laboratory of Organic Chemistry, Department of Chemistry, Faculty of Science, Institute of Technology Bandung and Laboratory of Research Center for Tea and Quinine, Gambung, Ciwidey, Bandung.

Cultured macrophages can be providing by the isolation of Mouse Peritoneal Macrophages. Macrophage culture purity was measured using the CD 11B marker by Flowcitometry until have more than $80 \%$ of purity.

Macrophages were cultured in T25 culture flasks with medium RPMI 1640. Experiments conducted when the cells were $90 \%$ confluent. Foam cell formation performed by the addition of ox-LDL in macrophages culture medium. After 72 hours of exposure ox-LDL, the media are removed to free ox-LDL, furthur given the treatment with Catechins. Foam cell formation and administration Catechins were performed in cultured macrophages $\left(1 \times 10^{6} / \mathrm{ml}\right)$ and incubated with ox LDL $(100 \mu \mathrm{g} / \mathrm{ml})$ for 72 hours. At the end of the incubation medium is removed and replaced with a new medium and given treatment for 24 hours. Measured the expression of ABCA1, ABCG1 and SRB1 after 72 hours of exposure to oxLDL [12].

\subsection{Real-Time PCR mRNA Analysis}

RNA was isolated from cultured macrophage with the RNeasy-mini kit according to the manufacturer's guidelines. Concentration of RNA was determined by measuring absorbance at $260 \mathrm{~nm}$ (A260). The A260/A280 ratio of the samples ranged from 1.8 to 2.2. Real-time PCR assays were carried out using SYBR green PCR Master Mix on a GeneAmp 5700 Sequence Detection System (Applied Biosystems) according to the manufacturer's protocol. Results were normalized to GADPH (housekeeping gene) expression [12] [13].

\subsection{Western Blot Analysis}

Aortic and hepatic protein levels of markers involved in RCT (ATP binding cassette A-1 [ABCA-1], ATP binding cassette G-1 [ABCG1] and scavenger receptor BI [SR-BI]) were analysed by Western blot analysis. Aortic and liver segments were excised, removed of surrounding adherent and connective tissue. Thereafter, the liver and aorta tissues were homogenized in lysis buffer $(50 \mathrm{mmol} / \mathrm{l}$ Tris- 
$\mathrm{HCl}, 1 \mathrm{mmol} / \mathrm{l}$ ethylenediaminetetraacetic acid (EDTA), 1\% Triton X-100, 0.1 $\mathrm{mg} / \mathrm{ml}$ PMSF, $1 \mathrm{~g} / \mathrm{ml}$ aprotinin, $10 \mathrm{~g} / \mathrm{ml}$ leupetin, $\mathrm{pH}$ 7.4, briefly sonicated. Consentration of protein were measured by nanodrop instrument. Samples ( $50 \mathrm{~g} / \mathrm{lane})$ were subjected to SDS-PAGE and transferred to nitrocellulose membranes. Blots were placed in Tris-buffered saline, 0.05\% Tween 20 (TBST) supplemented with PBS containing 3\% BSA for 2 hrs at room temperature and then incubated with ABCA-1, ABCG1 and SRB1 overnight at $4^{\circ} \mathrm{C}$. The blots were washed three times with TBS-Tween, and the membranes were incubated with horseradish peroxidase-conjugated antibodies for $1 \mathrm{hr}$ at room temperature and washed again as described previously [12] [13].

\subsection{Statistical Analysis}

Data are presented as mean $\pm \mathrm{SD}$ of five replication. Statistical differences between multiple groups were determined by analysis of variance (ANOVA) Statistical comparations were made using of Tukey test. Difference were considered significant at $\mathrm{p}<0.05$.

\section{Result}

Results Isolation of macrophages from the Mouse Peritoneum Macrophage (MPM). To determine the number of the isolated cells was measured by hematositometer as shown in Table 1.

The number of macrophages ranged between 0.5 up to $1 \times 10^{6}$ macrophages per mouse [14] [15]. Isolated macrophage cells were confirmed using Flowsitometry with CD11B marker (Figure 1).

The identification results using CD $11 \mathrm{~B}$ marker shows $94.83 \%$ and $81.64 \%$ of the population of cells are macrophages. These results are used guidelines for primary culture MPM. Additionally performed microscopy for characterization of macrophage cells from isolated MPM (Figure 2).

Induced ox-LDL of $50 \mathrm{mg} / \mathrm{L}$ in cell culture for 72 hours aimed to formation of foam cells. Cell foam that is formed can be observed by staining with Oil Red O to be stained orange as shown in Figure 3.

Determination mRNA of ABCA1 ABG1, SRB1 on cultured Macrophages.

Table 1. Number of isolated macrophage cells from Mouse Peritoneum Macrophages (MPM).

\begin{tabular}{cl}
\hline Sample & Macrophage Cells \\
\hline 1 & $1.19 \times 10^{6}$ cells $/ \mathrm{mL}$ \\
2 & $1.04 \times 10^{6}$ cells $/ \mathrm{mL}$ \\
3 & $0.85 \times 10^{6}$ cells $/ \mathrm{mL}$ \\
4 & $1.10 \times 10^{6}$ cells $/ \mathrm{mL}$ \\
5 & $0.98 \times 10^{6}$ cells $/ \mathrm{mL}$ \\
Averages & $1.03 \times 10^{6}$ cells $/ \mathrm{mL}$ \\
\hline
\end{tabular}



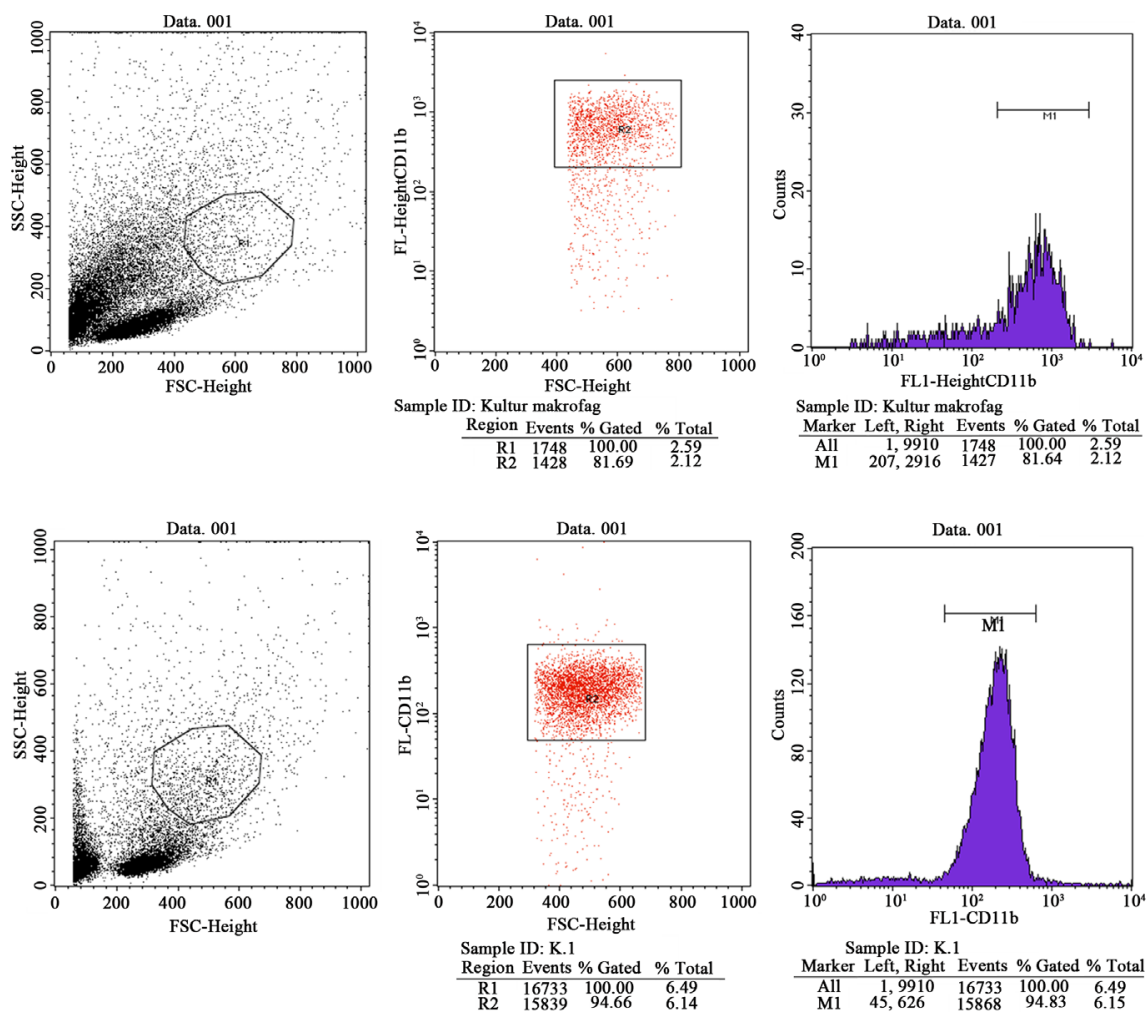

Figure 1. The identification of macrophage cells with flowsitometri CD 11B marker.

Amplification curve of mRNA ABCA1, ABCG1 and SRB1 shows in Figure 4.

There are differences in $\mathrm{CP} / \mathrm{Ct}$ between the treatment groups in which small $\mathrm{Ct}$ value indicates the high value quantification of mRNA.

Quantification of mRNA ABCA1, ABCG1, SRB1 in cultured macrophage (Table 2).

Statistical analysis showed that there is significant increase mRNA ABCA1 significantly in dose $50 \mu \mathrm{M}$ and $100 \mu \mathrm{M}$ Catechins with $\mathrm{p}$ value 0.003 and 0.000 where the value is less than 0.05, whereas the mRNA ABCG1 significant decrease in the third dose Catechins given. mRNA SRB1 significant decrease in dose of $50 \mu \mathrm{M}$ compared with the group that was exposed ox-LDL with $\mathrm{p}$ value 0.039 (Table 2).

Expression of the protein with $70 \mathrm{kDa}$ of molecular weight increased in a dose of $25 \mu \mathrm{M}$ and $50 \mu \mathrm{M}$ while $100 \mu \mathrm{M}$ dose decreased expression (Figure 5). The results of SDS-PAGE with Coumasine Blue shows only one protein band at almost the same molecular weight. Confirmation of the expression of ABCA1 protein, ABCG1 and SRB1 by western blotting could not be detected.

Characterization of the isolated macrophages were done by identification with flowcytometry with CD 11B marker. Based hussell and Bell, 2014, CD 11 B surface marker is a Mouse Peritoneal Macrophage marker that is expressed in sufficient levels except CD14, F4/80, and class II of MHC. Characterization of macrophages by fluorescence using labeled monoclonal antibodies that specifically recognize a protein expressed by macrophages. Surface markers can be used to 


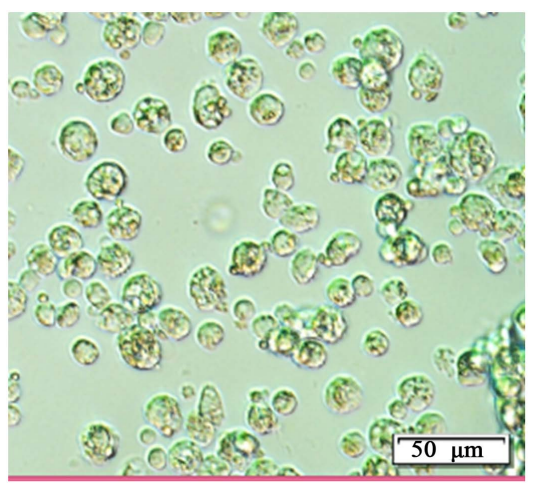

(a)

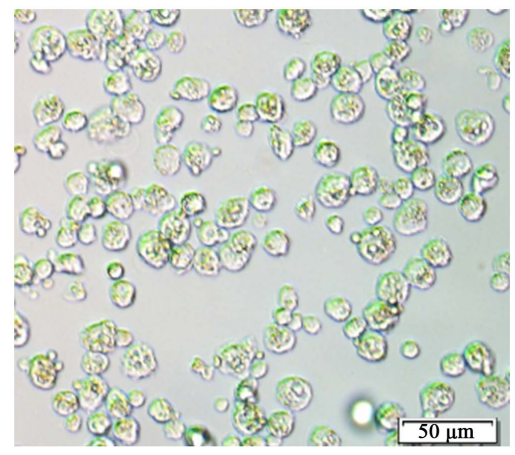

(c)

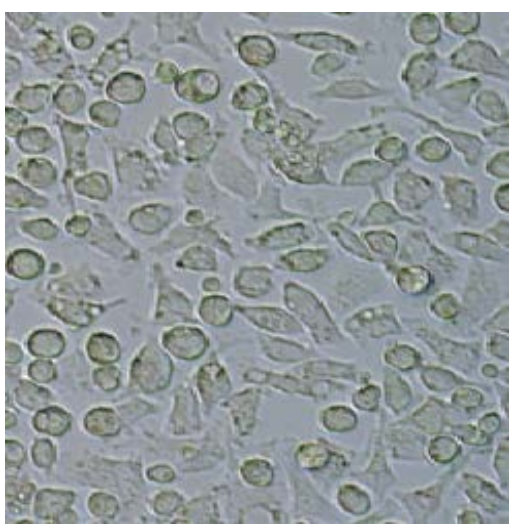

(e)

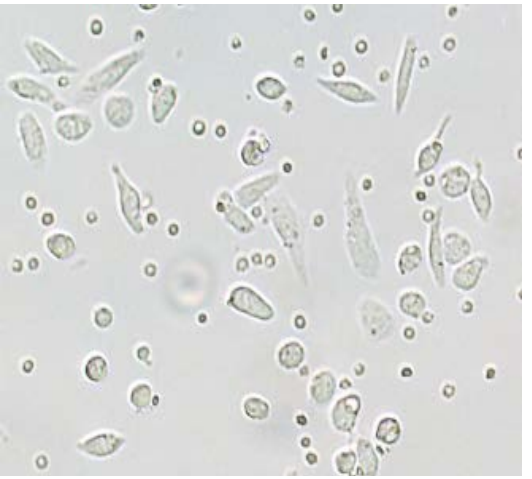

(b)

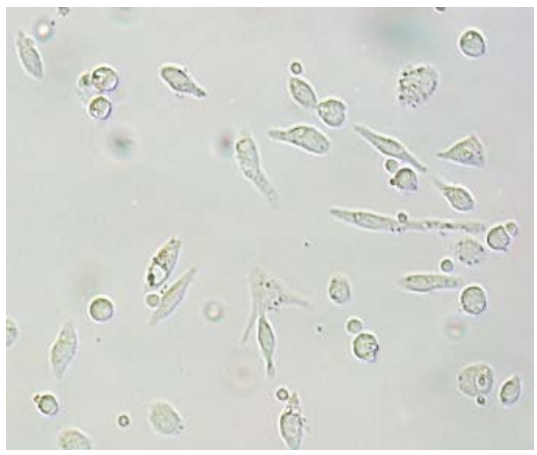

(d)

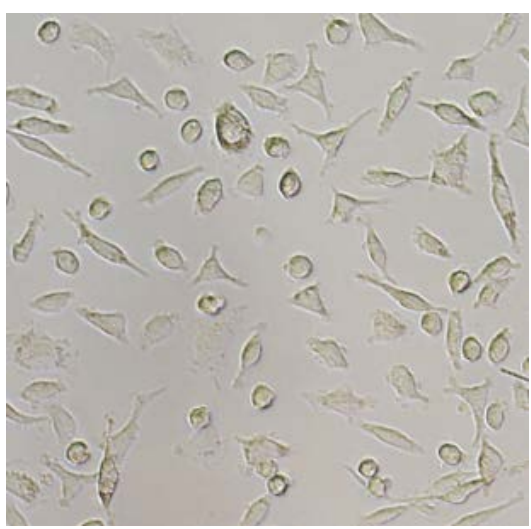

(f)

Figure 2. Results macrophage morphology culture. (a) culture of the macrophage day 1; (b) the culture of macrophages day 1 after being washed; (c) (d) replication to -2 ; (e) (f) Replication to -3 .

Table 2. Quantification of mRNA ABCA1, ABCG1, SRB1 in cultured macrophage.

\begin{tabular}{cccc}
\hline Sample & $\begin{array}{c}\text { mRNA ABCA1 } \\
\text { (number of copied) }\end{array}$ & $\begin{array}{c}\text { mRNA ABCG1 } \\
\text { (number of copied) }\end{array}$ & $\begin{array}{c}\text { mRNA SRB1 } \\
\text { (number of copied) }\end{array}$ \\
\hline Control - & $251,009 \pm 6475.5$ & $1,441,469 \pm 50,237$ & $311,759 \pm 6579.8$ \\
Control + & $91,068 \pm 5704.3$ & $1,108,831 \pm 17,337$ & $289,978 \pm 1575.3$ \\
Dose $25 \mu \mathrm{M}$ & $163,583 \pm 2941.3$ & $625,803 \pm 5798.6$ & $278,091 \pm 22,094.7$ \\
Dose $50 \mu \mathrm{M}$ & $342,051 \pm 84,144$ & $371,635 \pm 16,532$ & $252,639 \pm 8485.6$ \\
Dose $100 \mu \mathrm{M}$ & $502,637 \pm 59,101$ & $296,746 \pm 2088.3$ & $260,631 \pm 3871.7$ \\
\hline
\end{tabular}



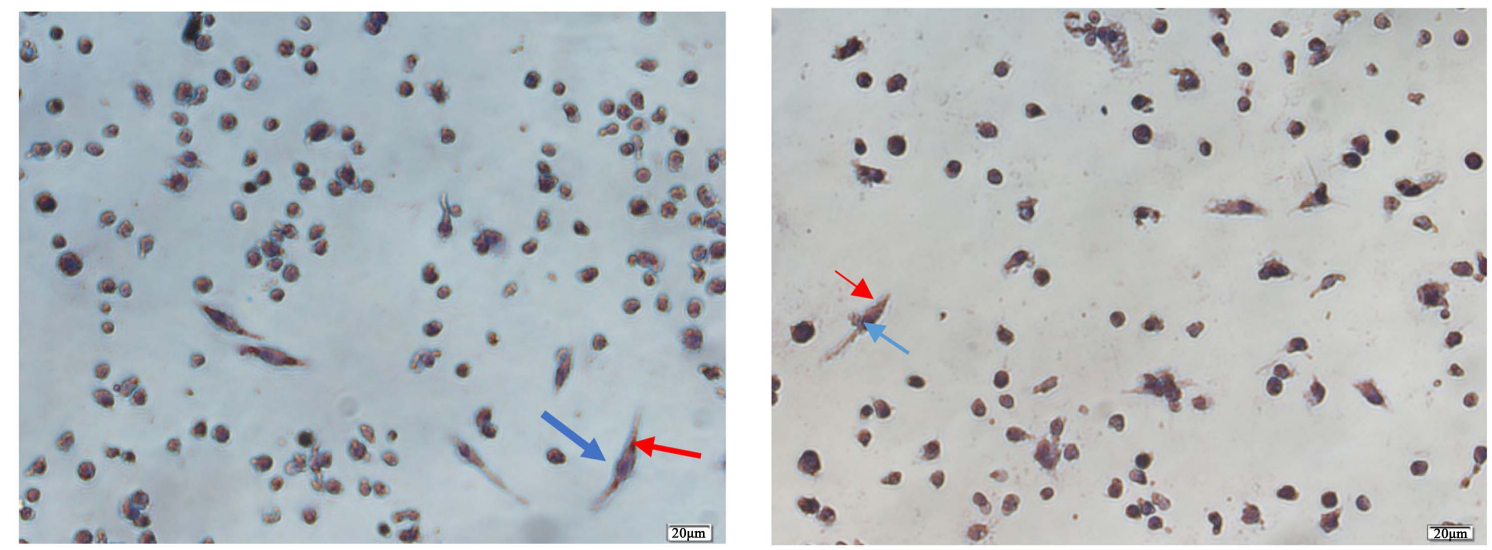

Figure 3. Results of oil red O staining of macrophage foam cells. Lipid droplets orange $(\rightarrow)$ while the cell nucleus is blue $(\rightarrow)$ ).
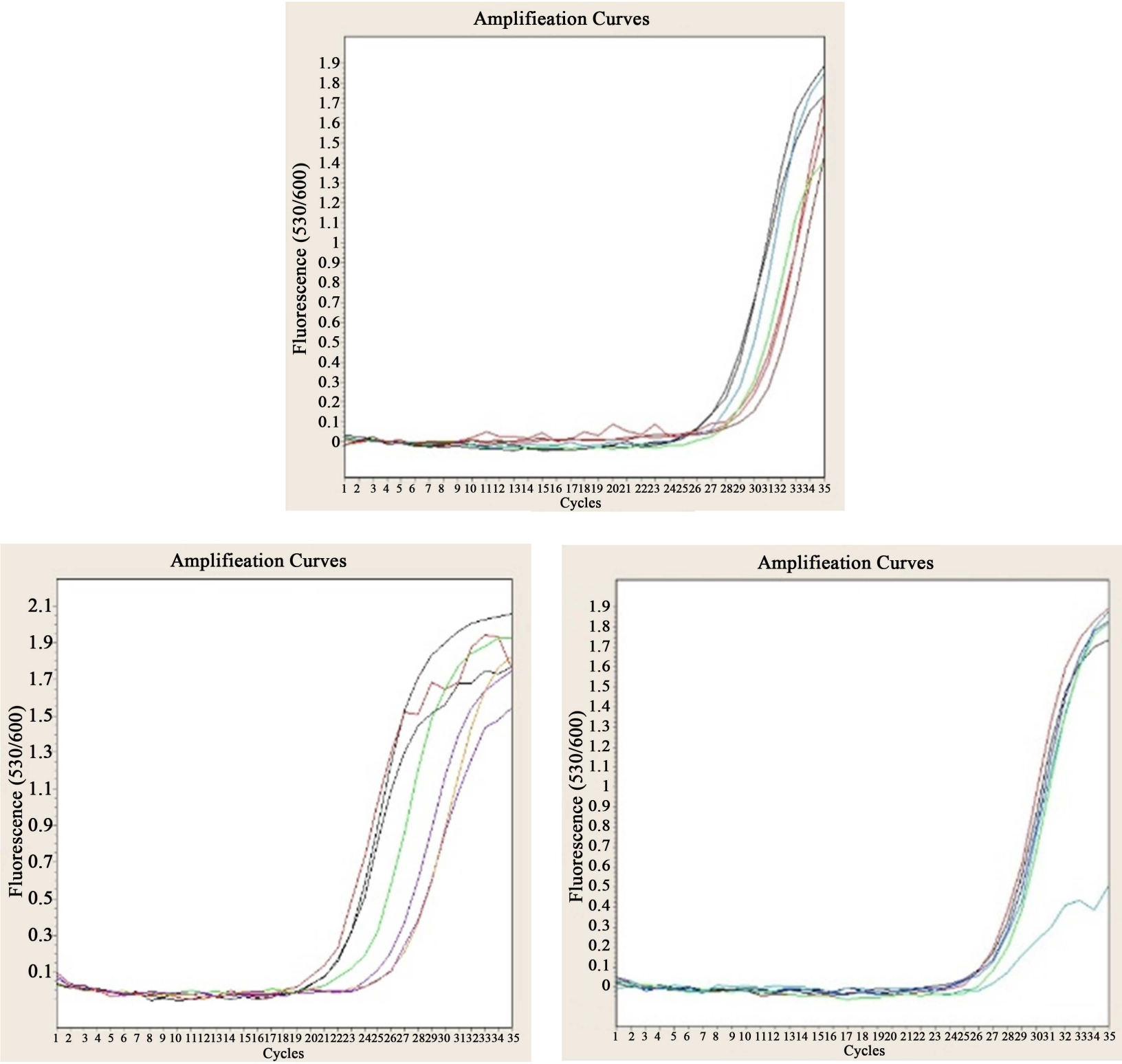

Figure 4. mRNA amplification curve of ABCA1, ABC G1, SRB1. 
Profiling protein of cell culture by silver staining

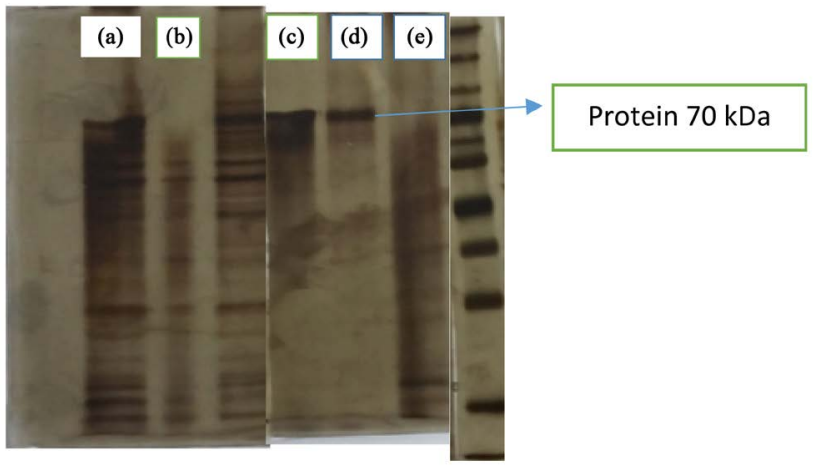

Figure 5. The Profiling Protein SDS-PAGE with Silver Staining, The control group + (a), the control - (b), the dose I (c), dose II (d) and dose III (e) indicate the presence of a protein with a molecular weight of $70 \mathrm{kDa}$ whose expression is increased in a dose $25 \mu \mathrm{M}$ and $50 \mu \mathrm{M}$ of Catechins.

distinguish macrophages with other cells in a heterogeneous cell population. Flowcytometry can identify and sort out the desired cell in a heterogeneous cell population. $\mathrm{CD} 11 \mathrm{~B}$ is a specific marker for identifying macrophages in addition to CD68 and F4/80 [16]. The results of cell culture macrophage morphology compared with literature review, research Kim 1997 showed morphological characteristics similar to the results of research that has been done [17]. So that is in accordance with research conducted by Wang et al., 2010 [18]. To induce the formation of foam cells given ox-LDL of $50 \mathrm{mg} / \mathrm{L}$. The treatment conditions consistent with research Ming Su et al., 2015 conducted research on cells U 937 incubated with ox-LDL concentrations are different start $0 ; 25 ; 50 ; 75 ; 100$ and $125 \mathrm{mg} / \mathrm{L}$ and done with oil red $\mathrm{O}$ staining showed that the concentration of 50 $\mathrm{mg} / \mathrm{L}$ is an optimal concentration for the formation of foam cells [19]. Other studies have linked foam cells staining with Oil Red O staining demonstrated by Kinkel et al., 2004, The result Oil Red O propylene staining in 3T3-LI cells which the lipid droplets red/orange and the cell nucleus surrounded by clear boundaries [20].

The results show that Catechins dose of $50 \mu \mathrm{M}$ and $100 \mu \mathrm{M}$ in significant increases ABCA1 mRNA, whereas ABCG1 mRNA decreased at all three doses given Catechins. SRB1 mRNA decreased significant at doses of $50 \mu \mathrm{M}$. These results indicate that the main pathway of cholesterol efflux via ABCA1 by increasing ABCA1 mRNA at a dose of $50 \mu \mathrm{M}$ for optimum Catechins with small doses has been able to provide the expected effect. There are several pathways cholesterol efflux from foam cells are fused to intermediary water, via ABCA1, ABCG1, SRB1 and endogenous product of Apo E lower lipids. In normal murine macrophage cholesterol diffusion dominant aquoeus while macrophages with cholesterol exposure $\mathrm{ABC}$ transporter dominant. Efflux path relative contributions are 35\% ABCA1, diffusion aquoeus 35\%, 21\% and SRB1 ABCG1 9\%. Diffusion aquoeus that determines the speed of desorption effluks is free cholesterol from the plasma membrane into the surrounding water phase while being ac- 
ceptor in this pathway is the HDL-L, HDL and HDL-M-S. Efflux is not influenced by the size of HDL particles [21]. Widely accepted that HDL protects atherosclerosis by way of removing excess cholesterol from the cells by an active process mediated by membrane transporter ABCA1 [22]. Induction efflux cholesterol by inducing up-regulation of expression ABCA1 mRNA. Up regulation is in line with research Xia et al., 2005 where the provision of transcription inhibitor that inhibits the expression actinomisin $\mathrm{D}$ and efflux cholesterol by binding to DNA. ABCA1 transcription occurs through activation of nuclear receptors LXR LXR both $\alpha$ and $\beta$ LXR and RXR. Giving an LXR antagonist that is significant G6PP negate ABCA1 mRNA expression and efflux cholesterol. Catechins work through the mechanism of activation of $\operatorname{LXR} \alpha$. The regulation of gene expression by binding to the LXR element of ABCA1 promoter. Upstream regulation of LXR $\alpha$ and ABCA1 adalagh PPAR $\gamma$ a group of nuclear receptors that regulate genes involved in lipid homeostasis. PPAR $\gamma$ antagonist GW 9662 is signifcant decrease the expression of ABCA1. Confirmation of protein expression by western blotting cannot be detected transporter protein being targeted. While the SDS-PAGE silver staining identified the protein with a molecular weight of $70 \mathrm{kDa}$ that needs to be further explored to identify the protein expression is associated with macrophage cholesterol efllux.

\section{Conclusions}

Based on the results of research and discussion, it can be summed up as follows:

1) Catechins increase mRNA ABCA1 and decrese mRNA ABCG1 and SRB1 in cultured macrophages were exposed ox-LDL.

2) Catechins increase the expression of the protein with a molecular weight of $70 \mathrm{kDa}$ based on the results of SDS-PAGE with silver staining in cultured macrophages were exposed ox-LDL.

\section{Acknowledgements}

This work was supported by a grant of Directorate of General Higher Education, Ministry of Education and Culture of Indonesia for the Grant Doctoral Dissertation 2015.

\section{Conflicts of Interest}

The authors declare no conflicts of interest regarding the publication of this paper.

\section{References}

[1] American Heart Association Statistics Committee and Stroke Statistics Subcommittee (2007) Heart Disease and Stroke Statistics-2007 Update. A Report from the American Heart Association Statistics Committee and Stroke Statistics Subcommittee.

[2] Miller, Y.I., Choi, S.H., Fang, L. and Tsimikas, S. (2010) Lipoprotein Modification and Macrophage Uptake: Role of Pathologic Cholesterol Transport in Atherogene- 
sis. Subcellular Biochemistry, 51, 229-251.

https://doi.org/10.1007/978-90-481-8622-8_8

[3] Ono, K. (2012) Current Concept of Reverse Cholesterol Transport and Novel Strategy for Atheroprotection. Journal of Cardiology, 60, 339-343. https://doi.org/10.1016/j.jjcc.2012.07.014

[4] Calkin, A. and Tontonoz, P. (2010) LXR Signaling Pathway and Atherosclerosis. Arteriosclerosis, Thrombosis, and Vascular Biology, 30, 1513-1518. https://doi.org/10.1161/ATVBAHA.109.191197

[5] Zhang, Y., Da Silva, J.R., Reilly, M., Billheimer, J.T., Rothblat, G.H. and Rader, D.J. (2005) Hepatic Expression of Scavenger Receptor Class B Type I (SR-BI) Is a Positive Regulator of Macrophage Reverse Cholesterol Transport in Vivo. Journal of Clinical Investigation, 115, 2870-2874. https://doi.org/10.1172/JCI25327

[6] El Bouhassani, M., Gilibert, S., Moreau, M., Saint-Charles, F., Treguier, M., Poti, F., Chapman, M.J., Le Goff, W., Lesnik, P. and Huby, T. (2011) Cholesteryl Ester Transfer Protein Expression Partially Attenuates the Adverse Effects of SR-BI Receptor Deficiency on Cholesterol Metabolism and Atherosclerosis. The Journal of Biological Chemistry, 286, 17227-17238. https://doi.org/10.1074/jbc.M111.220483

[7] Zhao, Y., Pennings, M., Vrins, C.L. and Calpe-Berdiel, L. (2011) Hypocholesterolemia, Foam Cell Accumulation, But No Atherosclerosis in Mice Lacking ABC-Transporter A1 and Scavenger Receptor BI. Atherosclerosis, 218, 314-322. https://doi.org/10.1016/j.atherosclerosis.2011.07.096

[8] Gui, T., Shimakodo, A., Sun, Y., Akasaka, T. and Muragaki, Y. (2012) Diverse Role of Macrofag in Atherosclerosis: From Inflammatory Biology to Biomarker Discovery. Mediators of Inflammation, 2012, Article ID: 693083. https://doi.org/10.1155/2012/693083

[9] Geyeregger, R., Zeyda, M. and Stulnig, T.M. (2005) Liver X Reseptor in Cardiovascular and Metabolic Disease Review. Cellular and Molecular Life Sciences, 63, 524-539. https://doi.org/10.1007/s00018-005-5398-3

[10] Ratnawati, R. and Ciptati, S. (2009) Isolasi EGCG dari Teh Hijau Klon GMB4 Jawa Barat. Laporan Program Insentif Riset Dasar. RISTEK Kementerian Negara Riset dan Teknologi.

[11] Velayutam, P. and Babu, L. (2008) Green Tea Catechins and Cardiovascular Health: An Update. Current Medicinal Chemistry, 15, 1840-1850. https://doi.org/10.2174/092986708785132979

[12] Cimmino, G., Ibanez, B., Vilahur, G., Speidl, W.S., Fuster, V., Badimon, L. and Badimon, J.J. (2009) Up-Regulation of Reverse Cholesterol Transport Key Players and Rescue from Global Inflammation by ApoA-I (Milano). Journal of Cellular and Molecular Medicine, 13, 3226-3235. https://doi.org/10.1111/j.1582-4934.2008.00614.x

[13] Shen, D.Z., Xin, S.L., Chen, C. and Liu, T. (2013) Effect of Atorvastatin on Expression of TLR4 and NF-kB p65 in Atherosclerotic Rabbits. Asian Pacific Journal of Tropical Medicine, 6, 493-496. https://doi.org/10.1016/S1995-7645(13)60081-4

[14] Cohn, Z.A. (1978) Activation of Mononuclear Phagocytes: Fact, Fancy, and Future. The Journal of Immunology, 121, 813-816.

[15] Velde, A.V. (2010) Reverse Choleterol Transport: From Classical View to New Insight. World Journal of Gastroenterology, 16, 5908-5915.

[16] Swirski, F.K., Libby, P. and Aikawa, E. (2007) Ly-6Chi Monocytes Dominate Hypercholesterolemia-Associated Monocytosis and Give Rise to Macrophages in Atheromata. Journal of Clinical Investigation, 117, 195-205. 
https://doi.org/10.1172/JCI29950

[17] Kim, T.S. and Cohen, E.P. (1997) Macrophage-Activating Factors Produced By Murine Leukemia X Fibroblast Hybrid Cells Stimulates Resistance Tomycobacterium Avium Complex. Archives of Pharmacal Research, 20, 225-233.

https://doi.org/10.1007/BF02976149

[18] Wang, X., Collins, H.L., Ranalletta, M., Fuki, I.V., Billheimer, J.T., Tall, A.R. and Rader, D.J. (2007) Macrophage ABCA1 and ABCG1, But Not SR-BI, Promote Macrophage Reverse Cholesterol Transport in Vivo. Journal of Clinical Investigation, 117, 2216-2224. https://doi.org/10.1172/JCI32057

[19] Rothblat, G.H. and Phillips, M.C. (2010) High Density Lipoprotein Heterogeneity and Function in Reverse Cholesterol Transport. Current Opinion in Lipidology, 21, 229-238. https://doi.org/10.1097/MOL.0b013e328338472d

[20] Rosenblat, M., Volkova, N., Coleman, R., Almagor, Y. and Aviram, M. (2008) Antiatherogenicity of Extra Virgin Olive Oil and Its Enrichment with Green Tea Polyphenols in the Atherosclerotic Apolipoprotein-E-Deficient Mice: Enhanced Macrophage Cholesterol Efflux. The Journal of Nutritional Biochemistry, 19, 514-523. https://doi.org/10.1016/j.jnutbio.2007.06.007

[21] Phillips, M.C. (2014) Molecular Mechanisms of Cellular Cholesterol Efflux. The Journal of Biological Chemistry, 289, 24020-24029. https://doi.org/10.1074/jbc.R114.583658

[22] Zhang, M., Li, L., Xie, W., Wu, J.F., Yao, F., Tan, Y.L., Xia, X.D., Liu, X.Y., Liu, D., Lan, G., et al. (2016) Apolipoprotein A-1 Binding Protein Promotes Macrophage Cholesterol Efflux by Facilitating Apolipoprotein A-1 Binding to ABCA1 and Preventing ABCA1 Degradation. Atherosclerosis, 248, 149-159.

https://doi.org/10.1016/j.atherosclerosis.2016.03.008 